\title{
A Reflection on the Implementation of Second National Fadama Development Project in Kaduna and Katsina States of Nigeria
}

\author{
Adam Adem Anyebe ${ }^{1}$, Ibrahim Kurfi Mudi ${ }^{1}$ \\ ${ }^{1}$ Department of Public Administration, Ahmadu Bello University, Zaria- Nigeria, Nigeria \\ Correspondence: Adam Adem Anyebe, Department of Public Administration, Ahmadu Bello University, Zaria- Nigeria, \\ Nigeria
}

Received: May 11, 2015 Accepted: June 17, 2015 Online Published: June 25, 2015

doi:10.11114/bms.v1i2.907

URL: http://dx.doi.org/10.11114/bms.v1i2.907

\begin{abstract}
This study attempts to reflect on the implementation of the Second National Fadama Project in Kaduna and Katsina states of Nigeria with a view to assessing whether the project implementation has been effective in reducing poverty among the participating communities. It was therefore, hypothesized that there is no significant relationship between the Community-Driven Development Strategy and effective implementation of Fadama II project in the area of access to rural financial services and poverty reduction in the host communities. The primary data were obtained through the use of questionnaire and personal interview while secondary data were sourced from books, journals, unpublished materials and internet. The study showed that there is a significant relationship between Community-Driven Development and effective implementation of the project in the host communities. The research recommended that to enhance the success of future projects, the government should not interfere with the activities of such projects, especially in the selection of members of such associations and government should provide loan facilities to the beneficiaries in order to boost their assets acquisition capacity.
\end{abstract}

Keywords: fadama, community-driven development, implementation, project, beneficiaries, poverty-reduction

\section{Introduction}

Nigeria has the largest market for goods and services in Africa, in addition to vast and fertile agricultural land. Likewise it produces and exports crude oil. In fact, Nigeria is the World's $7^{\text {th }}$ largest exporter of crude oil and the $6^{\text {th }}$ largest producer in the Organization of Petroleum Exporting Countries (OPEC), in addition to being endowed with gas and solid mineral resources. Such a country is easily, a good potential for effective poverty reduction and possibly eradication of absolute poverty (Thomas and Canagaraja, 2004), but unfortunately, majority of the country's population are living in abject poverty (Interim Poverty Reduction Strategy, 2001). Previous attempts by successive governments in initiating agricultural policies which aimed at achieving food security and development have failed due largely to inadequate funding, lack of effective coordination, control, monitoring and in some cases lack of commitment to the agreement procedures in the programmes and the strategy adopted for the implementation.

Many agricultural experts, researchers, and international donor agencies have seriously questioned the public sector approach to the funding and implementation of agricultural projects in Nigeria. These agencies argue that the approach has been largely responsible for the failures and wastages in the agricultural sector and also served as a blockade to serving as a means to poverty alleviation to the rural populace.

Successive governments in Nigeria went in search for an effective poverty alleviation programme in order to ensure that the rural populace is brought into a meaningful source of income in the area they specialize, which is the farming. This led the government to come up with such policies as Operation Feed the Nation, Green Revolution, Agricultural Development Projects and a host of others. In these programmes, agricultural loans and grants at low and sometimes at interest-free rates were given to the beneficiaries.

The government later turned attention to investment in infrastructure, reforming agricultural and rural research and advisory services, enhancing access to rural financial services. The Second National Fadama Project otherwise simply known as the National Fadama II Project was expected to involve the restructuring of the project's implementation agencies at all levels of governance, ensuring an effective coordination, monitoring, as well as involving the stake holders in the project's formulation process and the implementation using a new strategy which is community driven 
(Community-Driven Development, CDD), an element of participation theory. In spite of these efforts by the government, the rural people in Nigeria are still poor.

With the new strategy adopted for the implementation of the National Fadama II Project, this study raised this question: To what extent has the CDD strategy facilitated the National Fadama II project in achieving its objective of enhancing access to rural financial services as well as poverty reduction among Fadama Resource Users in Kaduna and Katsina states?.

The main objective of this study, therefore, is to assess the strategy for the implementation of the National Fadama II Project in Kaduna and Katsina states in the area of enhancing access to rural financial services and poverty reduction. It was thus, hypothesized that there is no significant relationship between the CDD strategy and effective implementation of Fadama II project in the area of access to rural financial services and poverty reduction in the host communities.

\section{Literature Review}

The research attempted to review some studies conducted by researchers in similar areas of study in order to extract from their findings and to see whether there were gaps in knowledge in the field. In a research by Haddad (2001) on Participation and Poverty Reduction: Issues, Theory and New Evidence for South Africa, it was revealed that interventions designed to reduce poverty are highly multidimensional. For instance, a public works scheme in a particular rural area may be designed to raise the income of a target group, e.g. women, create physical asset of a lasting value, and create community capacity or empowerment. Similarly, a micro credit facility may be given to the landless for income generating activities, while reaching a large number of households in a short period of time while maintaining high rates of repayment, and minimizing administrative costs. The study also showed that, participation by communities is very vital because there may be interventions where knowledge of local conditions is important and where costs of the acquisition of such knowledge by outsiders may be high. Secondly that community participation may reduce the likelihood of moral hazards or adverse selection of problems. For instance in a public works project which requires daily pay, involvement of the community in the hiring of labour may increase the likelihood that the deserving poor receive employment, while those with a propensity to shirk are excluded. Thirdly that community participation is better at verifying that activities related to interventions take place. An outsider may have difficulty in ensuring that what is said to be done is done or even done well but he can verify at any point in time the quality and authenticity of the work done.

The research also revealed that community participation encourages formation of groups or associations as the key to reducing poverty in the rural areas by way of getting loans with which they are going to finance their businesses. More so, the community associations help members to formulate and implement programmes that suit them (Haddad, 2001).

Though the study emphasized the benefits of community participation on poverty reduction, the research failed to show the importance of community contribution, monitoring and the organizational structure through which the implementation takes place. No matter how effective the participation is by communities, the structure through which the policies are implemented is very vital. The research, therefore, failed to address this area which the present study attempted to address.

In another study by Adegbite (2008) on the Impact of National Fadama Development Project II on Small Scale Farmers in Ogun State: Implications for Agricultural Financing in Nigeria, it was revealed that inadequacy and dearth of credit for financing agriculture have been a major constraint to agriculture and rural development in most developing nations, including Nigeria. The research employed the use of multi-stage stratified random sampling technique in the selection of the respondents.

The study also assessed the implementation of National Fadama I, and reported that it was mainly meant to promote simple low-cost irrigation technologies in an attempt to increase food production. But the National Fadama I had neglected the downstream activities like processing, preservation, conservation, and rural infrastructure support for increases in the rural economy. Also that the project did not take into consideration the farmers involvement in other areas of agriculture, like livestock, fisheries and poultry. This non-involvement restricted benefits to only crop producers and neglecting other agricultural beneficiaries. The study at the same time showed that the National Fadama II project had incorporated a community-driven development approach. This was because various Fadama Users, such as crop farmers, hunters, pastoralists, women, youth, vulnerable and marginalized, operating through their respective Fadama User Groups and Fadama Community Associations could reach consensus on how to use the community resources to their mutual advantage.

A research by Adeolu and Taiwo (2004) on the Impact of the National Fadama Facility in Alleviating Rural Poverty and Enhancing Agricultural Development in South-Western Nigeria revealed that agriculture is the locus of poverty in Nigeria. This, according to the research was so because agriculture remains the main stay of Nigerian economy, 
contributing about $40 \%$ of the Gross Domestic Product (GDP) and employing about $77 \%$ of the working population (UNDP, 2006).

The research also revealed the type of crops cultivated by the farmers, as leafy vegetables, okra, maize and tomatoes, which according to him had led to the increase of the income of the farmers by about three folds compared to base-line. However, the research did not discuss the type of approach adopted in the implementation of the project. Likewise the research did not discuss the importance of incorporating the beneficiaries in the implementation process, which the present study attempted to address.

Kudi (2008) undertook a study on analysis of the impact of National Fadama Development Project II in alleviating poverty among farmers in Giwa Local Government area of Kaduna State, Nigeria which revealed that the Fadama Development Project II had positively impacted on the participating farmers in the local government area. The programme had increased the income level, enhanced access to farm inputs at subsidized rate and increased training and knowledge of the participants. The study also highlighted some problems encountered by the beneficiaries of the programme like, high cost of maintenance of the irrigation facilities, inadequate farmland for farming as well as time wasting in processing the grants/credit facilities from the financial support institutions.

\section{Bottom-up Approach}

The bottom-up approach to policy implementation has its root from a study conducted by Wetherley and Lipsky (1977) which showed that the top-down approach lacked effective implementation between the bureaucrats and their clients at a street - level. On the other hand, the bottom-up approach sees the implementation process as involving negotiation and consensus building.

According to John (2001:12) bottom-up approach is an approach to the study of implementation that stresses the involvement of lower level bureaucrats and others who carry out public decisions. The ideas and influences of these actors feed back to the peak decision makers to influence policy - choices.

The bottom-up theory focuses on the discretionary decisions that each field worker or street - level bureaucrat feeds into the policy (Lipsky, 1980). The discretionary role in delivering services or enforcing regulations makes street level bureaucrats essential actors in implementing public policies. From the foregoing, therefore, it is a known fact that, implementing a policy involves discretion of the individual implementers. For instance, a public officer has discretion whenever the effective limits on his power leave him free to make a choice among possible courses of action or inaction. In other words, implementers have varying bands of discretion over how they choose to exercise the rules which they are employed to apply.

To this end, Sabatier (1999) synthesized the work of both approaches to create a set of conditions for effective implementation, thus:

1. The bottom-up approach takes into account its emphasis on networks which implementation structure demands. That is, it highlights the importance of involving the stakeholders in all the processes of the policy from initiation to implementation for an effective outcome.

2. The top-down approach takes into account the beliefs of the policy elites in the policy process i.e. from initiation to implementation.

3. Both have presented clear and consistent objectives.

4. Both have to have an account theory on how to bring about changes in the constitution of the beneficiaries or user groups.

5. That implementation structures are legally structured in order to enhance the livelihood of compliance with policy implementation.

6. Both approaches require committed and skillful implementers.

7. There is the need for the support of interest groups and sovereigns in the executive and legislature.

\section{Method of Data Collection}

\subsection{Primary Data}

To generate the primary data, a questionnaire designed and developed by the researchers was administered on the staff of the project at the three levels of government, i.e. federal, state and local governments. The questionnaire designed for the officials was both closed and open ended in order to allow the respondents express their views freely. The beneficiaries were engaged in an interview organised around the following issues: access to rural financial services as well as poverty reduction. Cluster sampling was used for the beneficiaries of the project, in which they were clustered according to their Fadama Community Associations (FCA). From each (FCA) four (4) Fadama Resource User Groups 
were selected randomly to serve as the sample population and sample size. And the stratified sampling was applied for the Officials of the project, in which they were stratified according to their levels of project implementation, i.e. federal, state and local governments.

\subsection{Secondary Data}

The secondary data primarily came from the following sources:

$>$ Project Implementation Manual

$>$ Mid-term Project Report

$>$ Project Completion Report

$>$ Literature on Implementation

$>$ Other Official Documents

$>\quad$ Journals and magazines

$>$ Internet

\subsection{Method of Data Presentation and Analysis}

Statistical analysis instruments adopted in the presentation of the data include both descriptive and inferential statistical tools. The statistical method employed the use of the non-parametric test by adopting chi-square analysis. The essence of this method is that it is used to compare differences between observed and expected (theoretical) frequencies.

The formula for calculating the Chi-square $\left(\mathrm{X}^{2)}\right.$ is thus:

$$
\begin{aligned}
& \mathrm{X}^{2}=\sum_{i} \sum_{j} \frac{(0 i j-E i j)^{2}}{E i j}, \text { this translated means: } \\
& \mathrm{O} i j=\text { observed frequencies in cell } i j . \\
& \text { Eij=. } \\
& \text { Sample size } i \text { total })(\text { column } j \text { total })
\end{aligned}
$$

The importance of Chi - square test is that it examines the extent to which the frequencies that are actually observed in the study differ significantly from the frequencies that are expected, if the null hypothesis (Ho) is true, (Osuala: 2005:173). The decision rule in the use of Chi-square is that: Ho - null hypothesis is accepted if the calculated value is less than tabulated value. And if the calculated value is greater than the tabulated value the Ho-null hypothesis is rejected, and the alternative $\left(\mathrm{H}_{1}\right)$ is accepted.

\begin{tabular}{|c|c|c|c|c|c|c|}
\hline \multicolumn{3}{|c|}{ Level of government } & Frequency & $\%$ & Valid \% & Cumulative $\%$ \\
\hline \multirow[t]{5}{*}{ Federal } & Valid & Very effective & 4 & 40.0 & 40.0 & 40.0 \\
\hline & & Effective & 4 & 40.0 & 40.0 & 80.0 \\
\hline & & Undecided & 1 & 10.0 & 10.0 & 90.0 \\
\hline & & Very ineffective & 1 & 10.0 & 10.0 & 100.0 \\
\hline & & Total & 10 & 100.0 & 100.0 & \\
\hline \multirow[t]{5}{*}{ Kaduna } & Valid & Very effective & 8 & 57.1 & 57.1 & 57.1 \\
\hline & & Effective & 3 & 21.4 & 21.4 & 78.6 \\
\hline & & Undecided & 2 & 14.3 & 14.3 & 92.9 \\
\hline & & Very ineffective & 1 & 7.1 & 7.1 & 100.0 \\
\hline & & Total & 14 & 100.0 & 100.0 & \\
\hline \multirow[t]{5}{*}{ Katsina } & Valid & Very effective & 6 & 54.5 & 54.5 & 54.5 \\
\hline & & Effective & 3 & 27.3 & 27.3 & 81.8 \\
\hline & & Undecided & 1 & 9.1 & 9.1 & 90.9 \\
\hline & & Ineffective & 1 & 9.1 & 9.1 & 100.0 \\
\hline & & Total & 11 & 100.0 & 100.0 & \\
\hline
\end{tabular}

\subsection{Data Presentation and Analysis}

Assessment of Fadama Activities in Kaduna and Katsina states

Table 1. Respondents Assessment of the Effectiveness of Community-Driven Development Approach

Source: SPSS generated data, 2014

Table 1 shows an assessment of the strategy applied in the implementation of the project, which is Community Driven Development (CDD). The strategy takes into cognizance the Community assets as the key in the development of the rural areas. The CDD treats poor people as assets and partners in development process, which build on their institutional 
resources.

The responses show that at the federal level, $40.0 \%$ and another $40.0 \%$ of the officials rated the strategy as very effective and effective respectively, while $57.1 \%$ and $21.4 \%$ of the respondents from Kaduna state rated the strategy as very effective and effective respectively. In Katsina state, $54.5 \%$ and $27.3 \%$ of the respondents rated the strategy as very effective and effective respectively.

The differences in opinion were expressed in the Borrower Project Completion Report (2013:15) by the Katsina state officials of the AfDB project in which they complained about how the project was implemented. The Project's Community-Driven Development procedure is limited due to the supply driven nature of the subprojects which have been specified in terms of type, number or allocation of subproject per state and local governments without taking into consideration the needs of the different beneficiaries and geographical nature of the different states, especially with respect to civil works.

Table 2. Beneficiaries Involvement in the Planning and Implementation Process of the Project

\begin{tabular}{lllllll}
\hline Level of government & & Frequency & $\%$ & Valid \% & Cumulative \% \\
\hline Federal & Valid & Strongly agree & 6 & 60.0 & 60.0 & 60.0 \\
& & Agree & 3 & 30.0 & 30.0 & 90.0 \\
& & 1 & 10.0 & 10.0 & 100.0 \\
\multirow{4}{*}{ Kaduna } & Disagree & 10 & 100.0 & 100.0 & \\
& Total & 7 & 50.0 & 50.0 & 50.0 \\
& & Strongly agree & 5 & 35.7 & 35.7 & 85.7 \\
& & Agree & 1 & 7.1 & 7.1 & 92.9 \\
\cline { 3 - 5 } Katsina & Disagree & 1 & 7.1 & 7.1 & 100.0 \\
& Valid & Strongly disagree & 14 & 100.0 & 100.0 & \\
& & Total & 5 & 45.5 & 45.5 & 45.5 \\
& & Strongly agree & 4 & 36.4 & 36.4 & 81.8 \\
& & Agree & 1 & 9.1 & 9.1 & 90.9 \\
& Undecided & 1 & 9.1 & 9.1 & 100.0 \\
& Disagree & 11 & 100.0 & 100.0 & \\
\hline
\end{tabular}

Source: SPSS generated data, 2014

Involvement of the beneficiaries in the planning and implementation is key to the project's strategy. This led the researchers to ask questions as to whether the beneficiaries were involved and the level of involvement. From the responses in table 2, the beneficiaries were involved in the planning and implementation of the project in the two states. The result shows that $60.0 \%$ of the respondents from the federal level strongly agreed that the beneficiaries were involved in the planning and implementation of the project while 30.0\% agreed with the statement. From Kaduna State, $50.0 \%$ and $35.7 \%$ of the respondents respectively, strongly agreed and agreed that there was involvement of the beneficiaries in the project planning and implementation while $45.5 \%$ and $36.4 \%$ of the respondents from Katsina State, strongly agreed and agreed respectively that there was involvement of the beneficiaries in the project planning and implementation.

This result shows that there was an involvement of the beneficiaries in the planning and implementation process of the project, especially during the initial stage of the project when meetings were convened in order to inform and educate the beneficiaries on how to go about with their activities. However, an interview with the beneficiaries, especially the beneficiaries of the AfDB project, revealed that most of the beneficiaries were only involved during preliminary meetings, but when it came to financial matters they were kept in the dark even though they were made to open accounts with banks. This could have been one of the reasons why the officials recommended full CDD implementation in subsequent projects (interview,2013).During another session of interview, a shocking revelation emerged which supported the opinion expressed above. An interviewee (a beneficiary in Katsina State) revealed that political interference in the selection of beneficiaries was common (interview,2013). This situation might have been responsible for the imbalance and the inequitable distribution of facilities, especially loans in the host communities.

Some of the other challenges faced by the beneficiaries as revealed during the interview sessions were as follows: The Katsina state beneficiaries complained of their requests being ignored contrary to the instructions contained in the project implementation manual that allow them to decide on what sub-project they would want to have. Also there was a general complaint among the beneficiaries in the two states on the issue of marketing their produce after harvest. They all produced large quantities of commodity during the season, which made it difficult for them to sell and make good profit. There was also the problem of storage facilities, which made it difficult for them to preserve their surpluses. Another major challenge faced by the beneficiaries was inadequacy of funds to expand their Fadama activities which according to them could garner them more benefits and profit (Interview, 2013). 
Table 3. Effectiveness of Coordination during the Project Implementation.

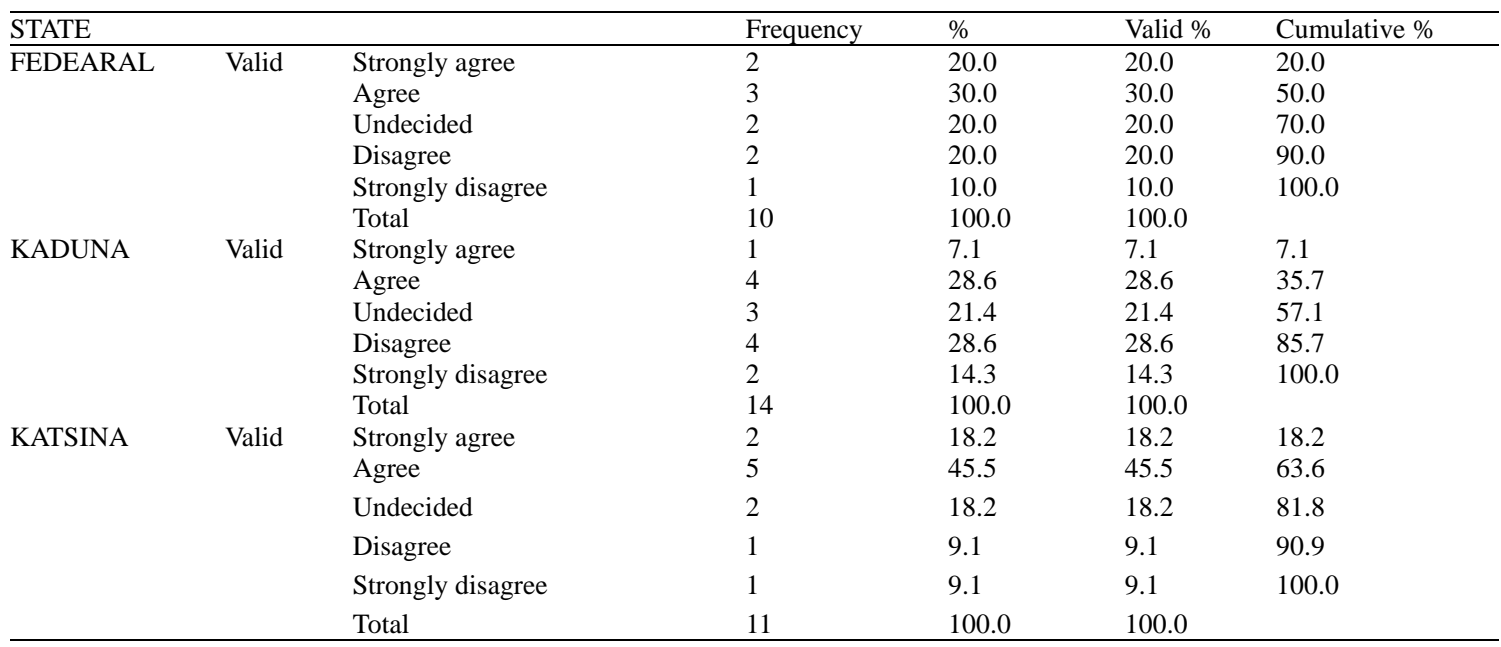

Source: SPSS generated data, 2014

Coordination is a key factor in the implementation of the Fadama project because it assists in ensuring that all the components are given the attention they deserve to ensure that the objectives are achieved.

Table 3 shows that $20.0 \%$ of the respondents from the federal level strongly agreed and $30.0 \%$ agreed with the statement that there was effective coordination during the project implementation while $20.0 \%$ and $10.0 \%$ respectively, strongly disagreed and disagreed with the statement. From Kaduna state, $7.1 \%$ and $28.6 \%$ respectively, strongly agreed and agreed with the statement. $14.3 \%$ strongly disagreed with the statement while $28.6 \%$ disagreed. $18.2 \%$ of the respondents from Katsina state strongly agreed with the statement while $45.5 \%$ agreed. $18.2 \%$ were undecided while $9.1 \%$ and another $9.1 \%$ respectively, strongly disagreed and disagreed with the statement. The essence of coordination according to Project Implementation Manual of (World Bank Fadama II, 2003:16) is that the Project management sub-component will support new or existing institutional entities and mechanisms at the federal, state and local levels of government for overall Project coordination and supervision and will help to strengthen the effectiveness and quality of Project operations. It will support at the federal level the National Fadama Development Office (NFDO), which is attached to the Project Coordination Unit of FMARD, and which will be responsible for overall Project coordination. The component will also support the State Fadama Development Office (SFDO), housed in the Agricultural Development Project office in the state. At the local government level, the Project will support a Local Fadama Desk (LFD) and multi-stakeholder committee which will be responsible for, respectively, screening and approving LDPs and subproject proposals submitted by the FCAs. The Project will finance specialized technical assistance and training at the federal, state, and local levels aimed at developing capacity for coordination of implementation.

The Project Development Objective is to reduce poverty by improving the living conditions of the rural poor, contribute to food security and increase access to rural infrastructure. It is specially designed to enhance agricultural production, productivity and value addition for small holders and rural entrepreneurs in Fadama areas on a sustainable basis.

Table 4 shows the responses from the sampled states with regards to increase in beneficiaries' income, which invariably means poverty reduction for the beneficiaries. $30.0 \%$ and $40.0 \%$ of the respondents from the federal level respectively, strongly agreed and agreed that the project had led to increase in the beneficiary's income. From Kaduna state officials, $42.9 \%$ of the respondents strongly agreed with the claim while another $42.9 \%$ agreed with the same claim that the project implementation has increased the beneficiary's income. $45.5 \%$ and $36.4 \%$ of the respondents from Katsina state who were on AfDB project respectively, strongly agreed and agreed that the project had contributed to the poverty reduction for the beneficiaries.

When the beneficiaries were asked whether the project had improved their economic status? Most of them expressed their satisfaction with the project implementation, because their economic base was improved in a number of ways, such as increase in the acreage of their farmlands, number of their flocks, quantity of the farm products, and their ability to solve other household problems within some limit, which was not the case before the introduction of the project. This is supported by a study undertaken by Chikwendu (2007:77), when he investigated the income changes of the beneficiaries of Kaduna state Fadama project and stated that the beneficiaries income had increased with about 58.5\% compared to their base line income. The base line income of the beneficiaries was between the range of $237,562.20$ and $\$ 336,077.80$ per annum but according to the project completion report (PCR) of Katsina state project implementation (2013:15) the benefits which accrued to the beneficiaries showed an increase in the level of crop 
production and yield which constituted the major source of income of the beneficiaries and was about $55.2 \%$. The base line income of the beneficiaries according to the report was between the range of $\$ 104,293.60$ and $\$ 154,498.96$ per annum.

Table 4. Fadama Project has led to Increase in the Beneficiaries' Income.

\begin{tabular}{|c|c|c|c|c|c|c|}
\hline \multirow{7}{*}{$\begin{array}{l}\text { STATE } \\
\text { Federal }\end{array}$} & & & Frequency & $\%$ & Valid \% & Cumulative $\%$ \\
\hline & \multirow[t]{6}{*}{ Valid } & Strongly agree & 3 & 30.0 & 30.0 & 30.0 \\
\hline & & Agree & 4 & 40.0 & 40.0 & 70.0 \\
\hline & & Undecided & 1 & 10.0 & 10.0 & 80.0 \\
\hline & & Disagree & 1 & 10.0 & 10.0 & 90.0 \\
\hline & & Strongly disagree & 1 & 10.0 & 10.0 & 100.0 \\
\hline & & Total & 10 & 100.0 & 100.0 & \\
\hline \multirow[t]{5}{*}{ Kaduna } & \multirow[t]{5}{*}{ Valid } & Strongly agree & 6 & 42.9 & 42.9 & 42.9 \\
\hline & & Agree & 6 & 42.9 & 42.9 & 85.7 \\
\hline & & Disagree & 1 & 7.1 & 7.1 & 92.9 \\
\hline & & Strongly disagree & 1 & 7.1 & 7.1 & 100.0 \\
\hline & & Total & 14 & 100.0 & 100.0 & \\
\hline \multirow[t]{5}{*}{ Katsina } & \multirow[t]{5}{*}{ Valid } & Strongly agree & 5 & 45.5 & 45.5 & 45.5 \\
\hline & & Agree & 4 & 36.4 & 36.4 & 81.8 \\
\hline & & Undecided & 1 & 9.1 & 9.1 & 90.9 \\
\hline & & Disagree & 1 & 9.1 & 9.1 & 100.0 \\
\hline & & Total & 11 & 100.0 & 100.0 & \\
\hline
\end{tabular}

Source: SPSS generated data, 2014

Table 5. Fadama Project Implementation and Poverty Reduction for the Beneficiaries.

\begin{tabular}{|c|c|c|c|c|c|c|}
\hline STATE & & & Frequency & $\%$ & Valid \% & Cumulative $\%$ \\
\hline \multirow[t]{6}{*}{ Federal } & Valid & Strongly agree & 3 & 30.0 & 30.0 & 30.0 \\
\hline & & Agree & 1 & 10.0 & 10.0 & 40.0 \\
\hline & & Undecided & 4 & 40.0 & 40.0 & 80.0 \\
\hline & & Disagree & 1 & 10.0 & 10.0 & 90.0 \\
\hline & & Strongly disagree & 1 & 10.0 & 10.0 & 100.0 \\
\hline & & Total & 10 & 100.0 & 100.0 & \\
\hline \multirow[t]{6}{*}{ Kaduna } & Valid & Strongly agree & 3 & 21.4 & 21.4 & 21.4 \\
\hline & & Agree & 3 & 21.4 & 21.4 & 42.9 \\
\hline & & Undecided & 2 & 14.3 & 14.3 & 57.1 \\
\hline & & Disagree & 2 & 14.3 & 14.3 & 71.4 \\
\hline & & Strongly disagree & 4 & 28.6 & 28.6 & 100.0 \\
\hline & & Total & 14 & 100.0 & 100.0 & \\
\hline \multirow{6}{*}{ Katsina } & Valid & Strongly agree & 3 & 27.3 & 27.3 & 27.3 \\
\hline & & Agree & 2 & 18.2 & 18.2 & 45.5 \\
\hline & & Undecided & 4 & 36.4 & 36.4 & 81.8 \\
\hline & & Disagree & 1 & 9.1 & 9.1 & 90.9 \\
\hline & & Strongly disagree & 1 & 9.1 & 9.1 & 100.0 \\
\hline & & Total & 11 & 100.0 & 100.0 & \\
\hline
\end{tabular}

Source: SPSS generated data, 2014

The Project Development Objective is to reduce poverty by improving the living condition of the rural poor, contribute to food security and increase access to rural infrastructure. It is specially designed to enhance agricultural production, productivity and value addition for small holders and rural entrepreneurs in Fadama areas on a sustainable basis.

Table 5 shows the responses from the two sample states with regards to poverty reduction of the beneficiaries. $30.0 \%$ of the respondents at the federal level strongly agreed that the project implementation had led to the reduction in poverty among the beneficiaries while $10.0 \%$ agreed with the statement. $50.0 \%$ and $35.7 \%$ respectively, of the respondents from Kaduna state implementation office strongly agreed and agreed that the project had contributed to the poverty reduction among beneficiaries. In Katsina state Fadama implementation office, 54.5\% and $27.3 \%$ respectively, of the respondents strongly agreed and agreed with the claim that the project had contributed to poverty reduction of the beneficiaries.

This openion is supported by a study conducted by Edemode (20013:2) which revealed that $75.0 \%$ of Fadama user households, who benefited directly from project supported activities, had their average real incomes increased from $\$ 121,770.34$ baselines to $\$ 138,429.06$, representing $13.68 \%$ increase. The result shows that, $10.0 \%$ of replacement value of the common assets used by the FUGs for income generating activities is saved annually. A total sum of $\$ 1$, $580,281.00$ was saved out of the productive assets value of $\$ 34,013,582.00$, which represents $4.7 \%$ per annum.

\section{Hypothesis}

It was hypothesized that there is no significant relationship between the CDD strategy and effective implementation of Fadama II project in the area of access to rural financial services and poverty reduction in the host communities. 
Table 6. Effectiveness of CDD Approach * Involvement of the Beneficiaries in the project planning and Implementation cross tabulation

\begin{tabular}{|c|c|c|c|c|c|c|c|}
\hline & & \multicolumn{5}{|c|}{$\begin{array}{l}\text { How do you assess the involvement of the beneficiaries } \\
\text { In the project implementation }\end{array}$} & \multirow[b]{2}{*}{ Total } \\
\hline & & $\begin{array}{l}\text { Very } \\
\text { Effective }\end{array}$ & Effective & Undecided & Ineffective & $\begin{array}{l}\text { Very } \\
\text { ineffective }\end{array}$ & \\
\hline \multirow{5}{*}{$\begin{array}{l}\text { How do you } \\
\text { Assess the } \\
\text { Effectiveness } \\
\text { Of cdd approach }\end{array}$} & Very effective & 3 & 0 & 1 & 3 & 1 & 8 \\
\hline & Effective & 2 & 0 & 2 & 1 & 3 & 8 \\
\hline & Undecided & 0 & 4 & 3 & 1 & 0 & 8 \\
\hline & Ineffective & 2 & 1 & 2 & 0 & 0 & 5 \\
\hline & Very ineffective & 1 & 1 & 0 & 0 & 4 & 6 \\
\hline Total & & 8 & 6 & 8 & 5 & 8 & 35 \\
\hline
\end{tabular}

Source: Survey by the Researcher, 2014

Table 7.Chi-Square Tests

\begin{tabular}{llll}
\hline & Value & Df & Asymp. Sig. (2-sided) \\
\hline Pearson Chi-Square & $28.061^{\mathrm{a}}$ & 16 & .031 \\
Likelihood Ratio & 33.695 & 16 & .006 \\
N of Valid Cases & 35 & & \\
a. 25 cells (100.0\%) have expected count less than 5. The minimum expected count \\
$\quad$ is .71.
\end{tabular}

Tables 1 and 2as cross tabulated show that the calculated chi square of 28.061 is greater than tabulated chi square of 26.296 at $0.5 \%$ level of significance, and therefore the hypothesis is rejected, and the alternate hypothesis is accepted. This means that there is a significant relationship between the Community-Driven Development strategy and successful implementation of Fadama II project in the area of access to rural financial services and poverty reduction in the host communities.

\section{Major Findings of the Study}

The major findings of this study include the following:

1. The Fadama II Project encouraged the participation of the beneficiaries through formulation of Local Development Plans (LDPs) for funding so that they could operate and manage their property, however according to Katsina State Project Completion Report (PCR: 2013:18) the beneficiaries were largely excluded at the level of funding and this greatly reduced the value of the Project.

2. There was the issue of political interference in the selection of beneficiaries, especially at the local government level because of the benefits to be gained from the projects. This action, largely led to the imbalance and the inequitable distribution of facilities in the host communities.

3. The National Fadama Project II has enormous potentials for economic benefits which are capable of alleviating rural poverty through provision of adequate infrastructure facilities which can easily be maintained by the beneficiaries

4. The project was implemented through participatory approach of the CDD and had assisted in raising the income level of the beneficiaries to a level above what was projected in the Project Implementation Manual.

\section{Recommendations}

Considering the findings of the research, the following recommendations are made:

1. The non-inclusion of asset acquisition and input support which has reduced the face value of the Fadama II project in Katsina state, because it is only through this effort that the beneficiaries can acquire their own assets and have input support which could assist them improve their income capacity. This means that a similar project to be implemented by AfDB should allow full participation of beneficiaries in order to allow them choose the type of assets they want to acquire to boost their income capacity.

2. The selection of beneficiaries should be de-politicized at all levels of the project implementation, especially at the local level where personal interest becomes intense.

3. When next government is going to come up with development programmes, it should be effectively predicated and implemented based on CDD approach because of its inclusive benefits. This is because any project in which the beneficiaries are co-opted as participants, that project is likely to produce the expected result because the people will be proud to claim ownership of the project and not just mere beneficiaries.

\section{References:}

Adegbite, D. A. (2008). Impact of National Fadama Development Project II on Small Scale Farmers' Income in Ogun 
State: Implications for Agricultural Financing in Nigeria, Journal of Sustainable Development in Africa, 10(3).

Adeolu, B., \& Taiwo, A. (2004). The Impact of The National Fadama Facility in Alleviating Rural Poverty and enhancing agricultural Development in South-Western Nigeria, Kamla-Raj Journal of Social sciences, 9(3).

African Development Fund (2003). Fadama II Development Project, Project Implementation Manual

Edemode, L. (2013). Available at http://kwarafadama.org.ng

Federal Programme Support Unit (FPSU), (2005). Information Handbook on Local Government Scorecard Assessment of Local Environmental Economic Management Project (LEEMP).

Giwa Local Fadama Desk Office, (2008). Kaduna State Fadama II Development Project: Sub-Project Implementation Achievements, for the Period of 2004-2008.

Haddad, L. (2001). Who is Driving Developemnt? Mathie, A and Cunningham, G (eds). Reflections on The Transformative Potential of Asset-Based Community Developemnt. Occasional Paper Series, 5. Canada.

Interim Poverty Reduction Strategy (IPRS). (2001). Interim Poverty Reduction Strategy Paper, Office of the Vice President of Nigeria, Abuja. httP://kwarafadama.org.ng, 2013.

Interview Report (2013). Interview with Beneficiaries of Fadama II Project.

Irrigation Framing in Taraba State, Nigeria, in International Journal of Plant, Animal and Environmental Sciences.

John, H. (2001). Participation and Poverty Reduction: Issues, Theory, and New Evidence from South Africa, An International Food Policy Research Institute Discussion Paper, 98.

Katsina State Fadama Development Office, (2009). Brief of Implementation Progress of Fadama Development Project in Katsina State for ADB/NFDO Mid Term Review (MTR) Mission to Katsina State.

Katsina State Fadama Development Office, (2013). Borrower Project Completion Report (PCR).

KSACDP (1997). Mid Term Review of the International Fund for Agricultural Development (IFAD) Assisted Project. Draft Report No. KSACDP/PME/97/4Kwarafadama.org. 2010.

Kudi, T. M. (2008). Analysis of The Impact of National Fadama Development Project II (NFDP) in Alleviating Poverty among Farmers in Giwa Local Government area of Kaduna State, Nigeria. Ozean Journal of Applied sciences.

Lipsky, M. (1980). Policy Implementation for Service Delivery. In Brynard, P.A. (ed). A paper presented at Africa Association for Public Administration and Management at 27th (AAPAM) annual Round table conference, at Zambezi sun hotel, Livingstone, Zambia.

Local Environmental and Economic Management Project (LEEMP). (2005) FSU, Abuja, Nigeria. National Bureau for Statistics NBS, (2005). Poverty Profile for Nigeria, Abuja, Nigeria.

NFDO, (2005). Fadama Development Project: Poverty reduction and increased productivity through empowerment. Project coordinating unit, federal ministry of Agriculture and Rural Development, Abuja.

Oruonye, E. D. (2011). Reducing Rural Poverty and Developing Livelihood Opportunity through

Osuala, E. C. (2005). Introduction to Research Methodology. African First Publishers Ltd. Onisha. Project Implementation Manual (PIM), World Bank (2004).

Sabatier, P. A. (1999). Theories, in Sabatier of the Policy Process. Boulder Colorado. Westview Press.

Thomas, S., \& Canagaraja, S. (2002). Poverty in a Wealthy Economy: The Case of Nigeria's IMF Working Paper, Washington: htt/ideas.repel.org/pumfwpa/02114.html

UNDP, (2006). Human Development Report. A Pulication of the UNDP, New York. MacMillan.

Whetherley, R., \& Lipsy, M. (1977). Street-level Bureaucrats and Institutional Innovation: Implementing Special Education Reform. Harvard Education Review, 47(2). http://dx.doi.org/10.17763/haer.47.2.v870r1v16786270x

World Bank, (1991). Assistance Strategies to Reduce Poverty; a World Bank Policy Paper. Washington D.C. Department.www.fadama.net. 2005.

World Bank, (1992). Poverty and Welfare in Nigeria. Washington DC

World Bank, (2003). Community-Driven Development A study Methodology. Operations Evaluations.

World Bank, (2006). Empowerment and Poverty Reduction: A Source Book PREM D. Naryan ed.

World Bank. (1993). Poverty Reduction and the World Bank: Progress and Challenges. Washington DC.

\section{$(\mathrm{cc}) \mathrm{BY}$}

This work is licensed under a Creative Commons Attribution 3.0 License. 